\title{
REPEATED AND NON-REPEATED NUCLEOTIDE SEQUENCES IN DIPLOID AND POLYPLOID WHEAT SPECIES
}

\author{
R. MITRA and C. R. BHATIA \\ Biology and Agriculture Division, Bhabha Atomic Research Centre, Bombay-400085, India
}

Received 10.xi.72

\section{SUMMARY}

\begin{abstract}
Reassociation rate studies of dissociated DNAs from diploid, tetraploid and hexaploid wheat species revealed that all the species have a large proportion of their DNA which shows characteristics of repeated DNA, under the conditions used in the reassociation experiments (fragment size about 450 nucleotide pairs, incubation at $60^{\circ} \mathrm{C}$. in $0.12 \mathrm{M}$ phosphate buffer, $C_{0} t=100$ ).

The relative proportion of this fraction increased with ploidy in tetraploid and hexaploid wheat.

Genome size (amount of non-repeated DNA) was larger in hexaploid and tetraploid wheat in comparison with diploid wheat.

Heterologous reassociation of repeated and non-repeated fractions of DNAs showed considerably more divergence in the repeated sequences at both diploid and at polyploid levels.

Non-repeated sequences of wheat species showed greater homologies, and appear to be more conservative in composition.
\end{abstract}

\section{INTRODUGTION}

REAssociation studies of dissociated DNAs from a number of eukaryotic organisms have shown that a fraction of DNA reassociates very rapidly (Britten and Kohne, 1969; Kohne, 1970; Britten and Davidson, 1971). It has been established from the work of the Carnegie group (Carnegie Institution Year Books: 1964-1970) that reassociation of DNA essentially follows a bimolecular reaction, and the rate of reassociation provides a measure of the concentration of complementary sequences. Thus, the fast reassociating fraction represents those nucleotide sequences which are present in multiple copies which may not necessarily be exact, while the slow reassociating fraction comprises the nucleotide sequences which are not multiplied or multiplied to a low degree. The former has been referred to as repeated (or redundant, reiterated, repetitious) DNA and the latter as non-repeated (or non-repetitious, unique) DNA. However, repeated and non-repeated are operational definitions, always to be considered in terms of the criteria used for reassociation, especially size of DNA fragments, incubation temperature and salt concentration (Kohne, 1970; McCarthy and Farquhar, 1972). The precise role of the repeated DNA is not understood. However, it has been hypothesised that it may have a regulatory function (Britten and Davidson, 1969, 1971; Crick, 1971). In higher organisms, 33 to 66 per cent. of the total DNA is reported to be repeated (Britten and Kohne, 1969). DNA of higher plants investigated so far, seems to have a higher proportion of repeated DNA in comparison to DNA of animals (Bendich and McCarthy, 1970b) under similar reassociation conditions. It is also hypothesised that repeated DNA probably originates by sudden, disproportionate replication of particu- 
lar nucleotide sequences (Britten and Kohne, 1969; Britten and Davidson, 1971) which is described as saltatory replication.

Polyploidy has played an important role in the evolution of plants, especially so in the family Graminae (Stebbins, 1956). The sub-tribe Triticinae which includes species of wheat (Triticum L.) and its related species is one of the most intensively investigated group of plants from the evolutionary standpoint. Phylogenetic relationships between species have been established using geographical, morphological, cytogenetic and biochemical criteria. All the diploid species of Triticinae are believed to have evolved from a common unknown progenitor. Hybridisation between diploid wheat (Triticum monococcum L.) and another related diploid species followed by the doubling of chromosome number gave rise to $4 x$ wheat. Aegilops speltoides Tausch or a species closely related to it was inferred to be the B genome donor to $4 x$ and $6 x$ wheats on geographical, morphological (Sarkar and Stebbins, 1956) and cytological (Riley, Unrau and Chapman, 1958) evidences. However, in view of recent evidence, it seems doubtful if Aegilops speltoides as such contributed the B genome (Sears, 1968; Mitra and Bhatia, 1971; Johnson, 1972; Kimber and Athwal, 1972). Hybridisation between a $4 \bar{x}$ form of wheat and $A e$. squarrosa $\mathrm{L}$. and subsequent amphiploidisation accounted for the origin of $6 x$ wheat (Kihara, 1944; McFadden and Sears, 1944). Polyploidisation during the evolution of wheat has been accompanied by an increase in the total DNA content per cell (Rees and Walters, 1965).

In this group, DNA reassociation rate studies have been made for $6 x$ wheat and rye DNAs (Bendich and McCarthy, 1970a). Heterologous reassociation of barley, oat, rye and $6 x$ wheat DNA (Bendich and McCarthy, $1970 a$ ) has been investigated using the DNA bound to the nitrocellulose filters. This technique as well as the agar method used by Bolton et al. (1965) measured reassociation predominantly of the repeated DNA fraction, as they involved low concentration of nucleic acid and short incubation time. In the present experiments, DNA reassociation in solutions, followed by separation of double-stranded and single-stranded DNAs by hydroxyapatite (HA) thermal chromatography was used. This technique provides information on the reassociation of repeated as well as non-repeated nucleotide sequences. Bendich and McCarthy (1970b) used the same technique to estimate reassociation of total $2 x$ wheat DNA with $4 x, 6 x$ wheat and Ae. squarrosa DNAs.

Experiments were initiated in the present study to find out the extent of (1) repeated DNA in diploid and polyploid wheat species and (2) divergence of repeated and non-repeated DNAs in this group. The following aspects are reported in this communication:

(a) Reassociation rates of homologous DNA of $2 x, 4 x$ and $6 x$ wheat.

(b) Thermal elution of reassociated homologous repeated and nonrepeated DNA.

(c) Heterologous reassociation of repeated and non-repeated DNAs among diploid and polyploid species of Triticinae.

\section{Materials and methods}

A list of species examined in the present investigation is given in table 1 . Labelled compounds ( ${ }^{3} \mathrm{H}$-thymidine, ${ }^{14} \mathrm{C}$-thymine and $\mathrm{H}_{3}{ }^{32} \mathrm{PO}_{4}$ ) were 
obtained from the Isotope Division of this Research Centre. Other chemicals used were of analytical grade and fine biochemicals were supplied by Sigma or Calbiochem.

TABLE 1

Species examined

$2 n=2 \bar{x}=14$

Triticum monococcum $\mathrm{L}$. Aegilops speltoides Tausch Secale cereale $\mathrm{L}$.

$2 n=4 \bar{x}=28$

T. turgidum (L.) Thell. conv. durum

$2 n=6 \bar{x}=42$

$T$. aestivum ssp vulgare (Vill., Host) MacKey

$2 n=8 \bar{x}=56$

T. aestivosecale MacKey (T. aestivum $\times$ Secale cereale)
Genome

AA

$\mathrm{SS}(\mathrm{BB})$

RR

AABB

AABBDD

AABBDDRR

\section{(i) Preparation of $D N A$}

Seeds treated with a mercury fungicide (Ceresan, Bayer India) for 5 minutes were washed in sterilised water and germinated in sterilised petri dishes lined with Whatman No. 1 filter paper. After 72 hours the germinating seeds were either given $0.1 \mathrm{~m}$ phosphate buffer $p \mathrm{H} \mathrm{7,}{ }^{3} \mathrm{H}$-thymidine (50 $\mu \mathrm{c} . / \mathrm{ml}$; specific activity $(5300-6000 \mathrm{mc} / \mathrm{m} \cdot \mathrm{mole})$, thymine-2-14 $\mathrm{C}$ $(50 \mu \mathrm{c} . / \mathrm{ml}$.; Sp. activity $5 \mathrm{mc} . / \mathrm{m} . \mathrm{mole})$ or $\mathrm{H}_{3}{ }^{32} \mathrm{PO}_{4}(50 \mu \mathrm{c} . / \mathrm{ml}$.) in phosphate buffer $p \mathrm{H} 7$ at the rate of $0 \cdot 2-1 \cdot 0 \mu \mathrm{c}$./seedling and allowed to grow for another 5 days. Labelled and unlabelled DNA were extracted from 8-dayold shoots following the method described by Bendich and Bolton (1967) with small modifications. Precipitation with isopropanol and 2-ethoxyethanol was used besides RNAse treatment to remove, respectively, RNA and polysaccharides from the isolated DNA. Purified DNA was dissolved in $0.12 \mathrm{M}$ sodium phosphate buffer (PB), $p \mathrm{H} 6.8$ and passed through $46.5 \mathrm{~cm}^{\mathrm{s}}$ of packed Sepharose 4B (Pharmacia, Uppsala, Sweden), equilibrated with 0.12 м PB. DNA concentration was determined by diphenylamine as well as by measuring absorbance (A) at $260 \mathrm{~nm}$. on a Shimadzu spectrophotometer. For convenience, $0.02 \mathrm{~A}=1 \mu \mathrm{g} . / \mathrm{ml}$. of native DNA and $0.022 \mathrm{~A}$ $=1 \mu \mathrm{g} . / \mathrm{ml}$. of denatured DNA were used for all estimations. ${ }^{32} \mathrm{P}$ labelled $E$. coli DNA was isolated by the method of Marmur (1961).

\section{(ii) Shearing of $D \mathcal{N A}$}

DNA solution (4-10 ml.) in 0.12 м PB was chilled and sonicated with an MSE sonicator using $\frac{3}{4}$ inch probe for 1.5 minutes at full intensity. This did not cause any increase in the absorbance of the DNA solution. Molecular weight of the sonicated DNA was determined in sucrose gradients in a Beckman L2/65 preparative ultra-centrifuge using the method described by Van der Schans et al. (1969); the average molecular weight of the sonicated double stranded DNA was estimated as $2.7 \times 10^{5}$ daltons corresponding to 450 nucleotide pairs.

Sonicated labelled DNA yielded about 1-3 per cent. of the total radioactivity in the trichloroacetic acid (TCA) soluble fraction. Therefore the DNA was purified by $\mathrm{HA}$ chromatography at $60^{\circ} \mathrm{C}$. using $0.12 \mathrm{M} \mathrm{PB}$. 
Double stranded DNA was eluted with $0.5 \mathrm{~m} \mathrm{~PB}$ at $60^{\circ} \mathrm{C}$ and dialysed against distilled water and then lyophilised. DNA was dissolved in PB of appropriate molarity for further studies.

\section{(iii) Dissociation of sheared DNA}

DNA was dissociated by heating the solution in $0.12 \mathrm{M} \mathrm{PB}$ at $100^{\circ} \mathrm{C}$ for 5-7 minutes. About 28-33 per cent. hyperchromicity was observed in the dissociated DNA solution and no radioactivity was detected in the TCA soluble fraction when labelled DNA was heated in a similar way.

\section{(iv) $D \mathcal{N A}$ reassociation}

Dissociated DNA in 0.12 м PB or $0.36 \mathrm{M}$ PB was incubated for reassociation in screw capped glass tubes at $60^{\circ} \mathrm{C}$ in order to achieve desired $C_{0} t$ values $\left(C_{0} t=\right.$ number of moles of nucleotides/l. $\times$ time in seconds). After the desired period of incubation, samples were either directly fractionated on $\mathrm{HA}$ or were chilled immediately and stored at $-10^{\circ} \mathrm{C}$. Frozen samples were brought to $60^{\circ} \mathrm{C}$ before fractionation. Sample incubated in $0.36 \mathrm{M} \mathrm{PB}$ were diluted three times with water before fractionation.

\section{(v) Hydroxyapatite fractionation}

HA was prepared following the method described by Miyazawa and Thomas (1965). Commercial HA (Calbiochem) whenever used was regenerated by three boiling steps as described by the above authors. The jacketed chromatographic column used was similar to the one described by Miyazawa and Thomas (1965) except that the entire column was made of glass. Temperature of the column was maintained by circulating hot water from a Universal Thermostat Type U-3 (Veb Prufgeratewerk, Medingen, Germany). Column temperature was determined by a Temperature indicator (TI-1) fabricated by the Electronics Division of this Research Centre.

Fractionation procedures used were adopted from Britten and Kohne (1968). One hundred micrograms of DNA per $\mathrm{cm}^{3}$ of packed HA were used in separating reassociated and dissociated DNAs. DNA samples in $0.12 \mathrm{MPB}$ at $60^{\circ} \mathrm{C}$ were loaded on the $\mathrm{HA}$ column pre-equilibrated to $60^{\circ} \mathrm{C}$ and $0.12 \mathrm{M}$ PB. Three to five washes of $0.12 \mathrm{M}$ PB (double the size of HA bed volume) were used to elute single-stranded DNA. Similar washes with $0.5 \mathrm{M} \mathrm{PB}$ at $98^{\circ} \mathrm{C}$ were used to elute reassociated DNA.

Whenever required $A_{260 \mathrm{~nm}}$. was read for both $60^{\circ}$ and $98^{\circ} \mathrm{C}$. washings. DNA was precipitated with cold 5 per cent TCA $\left(2^{\circ}-4^{\circ} \mathrm{C}\right)$ after adding unlabelled calf thymus DNA to a final concentration of $100 \mu \mathrm{g} . / \mathrm{ml}$. The precipitate was collected on membrane filters (Sartorius) which were dried and then counted in a Beckman Liquid Scintillation System LS 100 using $10 \mathrm{ml}$. toluene containing PPO $(0.4$ per cent) and POPOP (0.05 per cent).

\section{(vi) Homologous $D \mathcal{N A}$ reassociation rate}

Sheared, labelled DNA was mixed with an excess of unlabelled homologous DNA and the mixture in $0.12 \mathrm{M} \mathrm{PB}$ was dissociated at $100^{\circ} \mathrm{C}$ and then incubated at $60^{\circ} \mathrm{C}$ for the required time to achieve appropriate $C_{0} t$ values. In order to achieve high $C_{0} t$ values in short incubation periods, and for the non-repeated fraction, DNA was incubated in $0.36 \mathrm{M} \mathrm{PB}$ which results in an increase of reaction rate by a factor of 4.47 (Britten, 1969). Reassociated DNA was fractionated as already described. 


\section{(vii) Heterologous $D \mathcal{N A}$ reassociation}

Sheared, labelled DNA from one species was mixed with the nonlabelled DNA of the other species in the ratio of $1: 100$ in $0.12 \mathrm{M}$ or $0.36 \mathrm{MPB}$, dissociated at $100^{\circ} \mathrm{C}$, brought to $60^{\circ} \mathrm{C}$ immediately and incubated at $60^{\circ} \mathrm{C}$ for the desired period. The final volume was kept 1-2 $\mathrm{ml}$. Reassociated DNA was separated by HA chromatography.

(viii) Percentage reassociation

Reassociation of DNA was calculated as follows:

$$
\text { Percentage reassociation }=\frac{A}{A+B} \times 100
$$

$\mathrm{A}=$ radioactivity or the amount of DNA as measured by absorbance eluted by $0.5 \mathrm{MPB}$ at $98^{\circ} \mathrm{C}$.

$\mathrm{B}=$ radioactivity or the amount of DNA eluted by $0.12 \mathrm{M} \mathrm{PB}$ at $60^{\circ} \mathrm{C}$.

(ix) Separation of repeated and non-repeated DNA

Reassociation data for the homologous DNA revealed that incubation at a $C_{0} t$ of 100 effected complete reassociation of repeated DNA from diploid, tetraploid and hexaploid wheat. Therefore, in order to separate the two DNA fractions, labelled or unlabelled, sheared, dissociated DNA was incubated in $0.12 \mathrm{M} P B$ to achieve $C_{0} t$ of 100 . Reassociated DNA was separated by $\mathrm{HA}$ chromatography. The dissociated single-stranded DNA which did not bind to the HA column was again incubated at $60^{\circ} \mathrm{G}$. and $C_{0} t 100$ and passed through the HA column. The fraction which did not bind to the HA column was considered as the non-repeated fraction. Reassociated DNA bound to the column was eluted with $0.5 \mathrm{M} \mathrm{PB}$ at $60^{\circ} \mathrm{C}$. Both repeated and non-repeated fractions were dialysed against water and lyophilised.

\section{(x) Thermal dissociation of repeated and non-repeated DNA}

Repeated and non-repeated fractions in appropriate $\mathrm{PB}$ were incubated at $60^{\circ} \mathrm{C}$ for the required time and then loaded on the HA column. The DNA which did not reassociate was washed off with $0.12 \mathrm{~m}$ PB. Column temperature was then raised gradually with increments of $3^{\circ} \mathrm{C}$, and two washings of $0.12 \mathrm{M} P B$ were collected 5 minutes after temperature equilibration. Absorbance or TCA precipitable radioactivity was determined for each fraction.

\section{(xi) Replication}

The experiments involving the homologous DNA reassociation rate were replicated twice while the values for heterologous reassociation are the means of two to three independent experiments, depending on the availability of the labelled DNA preparation of suitable specific activity.

\section{Results AND Discussion}

(i) Reassociation kinetics of homologous $D N A$

Reassociation rate curves for $2 x, 4 x, 6 x$ wheat and $E$. coli DNAs are given in fig. 1. E. coli DNA was used as a standard genome of known sequence diversity (Britten and Kohne, 1969). The $E$. coli reassociation rate curve is 
composed of one component, the central two-thirds of which spans less than $30 C_{0} t$ units. This is characteristic of genome consisting predominantly of non-repeated nucleotide sequences. $C_{0} t$ for 50 per cent reassociation of $E$. coli DNA under our experimental conditions was 4.3 . In contrast, all diploid and polyploid wheat reassociation curves were much broader and spread over large $C_{0} t$ units. The wheat curves show three distinct regions: (A) Rapidly

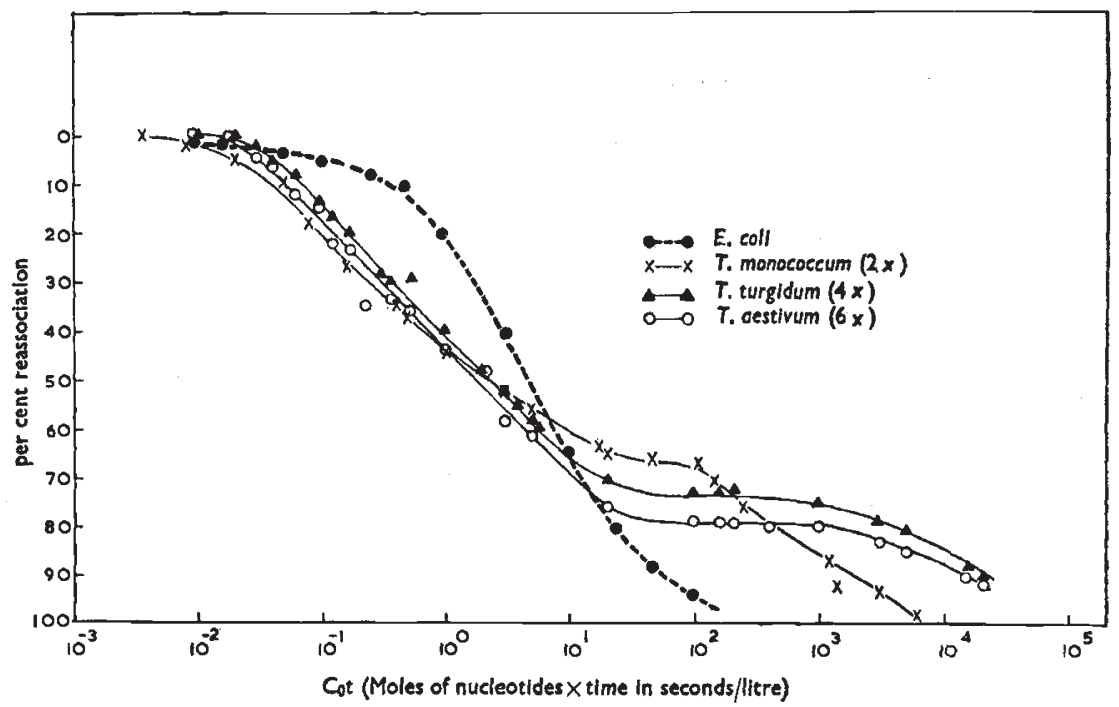

Frg. 1.-Reassociation rate curves for $E$. coli and wheat DNA's. Sheared ${ }^{32} \mathrm{P}$-labelled wheat and $E$. coli DNAs were used. DNA concentrations used to achieve $C_{0} t$ values between $0.0016-0.01,0.01-0 \cdot 32,0.5-150,150-1400$ and $1400-17,500$ for monococcum were $1 \mu \mathrm{g} . / \mathrm{ml}$. (c.p.m. 15,000), $10 \mu$ g. $/ \mathrm{ml}$. (150,000 c.p.m.), $100 \mu$ g. $/ \mathrm{ml}$. (150,000 c.p.m.), 1 mg. $/ \mathrm{ml}$. $(1,500,000$ c.p.m.) and $1.77 \mathrm{mg} . / \mathrm{ml}$. (1,500,960 c.p.m.), respectively. The concentrations of DNA are mentioned against each range of $C_{0} t$ for turgidum and aestivum are as

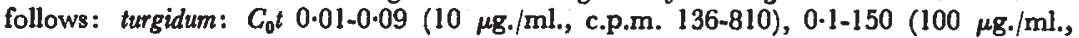
136,800 c.p.m.), 150-1000 (1 mg./ml., 1,368,000 c.p.m.), 1000-20,000 (5 mg./ml., 1,365,000 c.p.m.); aestivum: $10 \mu \mathrm{g} . / \mathrm{ml}$. (124,860 c.p.m.), $100 \mu \mathrm{g} . / \mathrm{ml}$. (124,800 (c.p.m.), $1 \mathrm{mg} . / \mathrm{ml}$. (1,248,000 c.p.m.), and $5 \mathrm{mg} . / \mathrm{ml}$. $(1,245,000$ c.p.m. for the same range of $C_{0} t$ values as mentioned above. For $E$. coli the DNA concentration used was $10 \mu \mathrm{g} . / \mathrm{ml}$. (c.p.m. 182,480) and $100 \mu \mathrm{g} . / \mathrm{ml}$. (1,824,800 c.p.m.) to achieve $C_{0} t 0.009-0.1$ and $0.1-100$, respectively. DNA in $0.12 \mathrm{MPB}$ was dissociated at $100^{\circ} \mathrm{C}$. and quickly transferred to $60^{\circ} \mathrm{C}$. for desired period of incubation. An aliquot of $1 \mathrm{ml}$. for the DNA concentrations $10-100 \mu \mathrm{g} . / \mathrm{ml}$. and $0.2 \mathrm{ml}$. for $1.5 \mathrm{mg} . / \mathrm{ml}$. was taken out from the reaction mixture and frozen immediately. Percentage reassociation was calculated after HA fractionation.

reassociating region extending from 0.01 to $10 C_{0} t$ where about $60-70$ per cent of the DNA reassociates. (B) Central region between $C_{0} t 10-100$ which shows only slight increase in percentage reassociation with increase in $C_{0} t$ value. (C) Slow reassociating region where duplex formation requires very high $C_{0} t s$.

The rapidly reassociating fraction comprises of about 67,74 and 80 per cent of the total DNA in $2 x, 4 x$ and $6 x$ wheat respectively. The $C_{0} t$ required for the reassociation of this DNA fraction was much less than that needed for the reassociation of the slow fraction. This suggests the presence of multiple copies of nucleotide sequences or what is considered as repeated DNA. Similarities of the diploid and polyploid wheat curves in the fast 
reassociating region also indicate that, probably, new families of repeated sequences resulting from saltatory replication have not appeared extensively since the evolution of polyploid species.

The slow reassociating fraction that needs high $C_{0}$ ts for duplex formation comprises of nucleotide sequences that occur probably once in the genome (Britten and Kohne, 1968; Laird, 1971). Since the time required for the reassociation of dissociated strands of DNA depends, primarily, on the number of different sequences and their relative concentrations (number of copies/ genome) (Britten and Kohne, 1968), the displacement of the wheat slow reassociating fraction towards the right, in comparison to the $E$. coli curve, implies a much larger genome size (amount of DNA per typical unique sequence) for wheat.

(ii) Thermal elution of reassociated homologous repeated and non-repeated DNA

Thermal elution curves for reassociated repeated and non-repeated DNAs from $2 x, 4 x$ and $6 x$ wheat, separated after reassociation at $C_{0} t 100$ on the

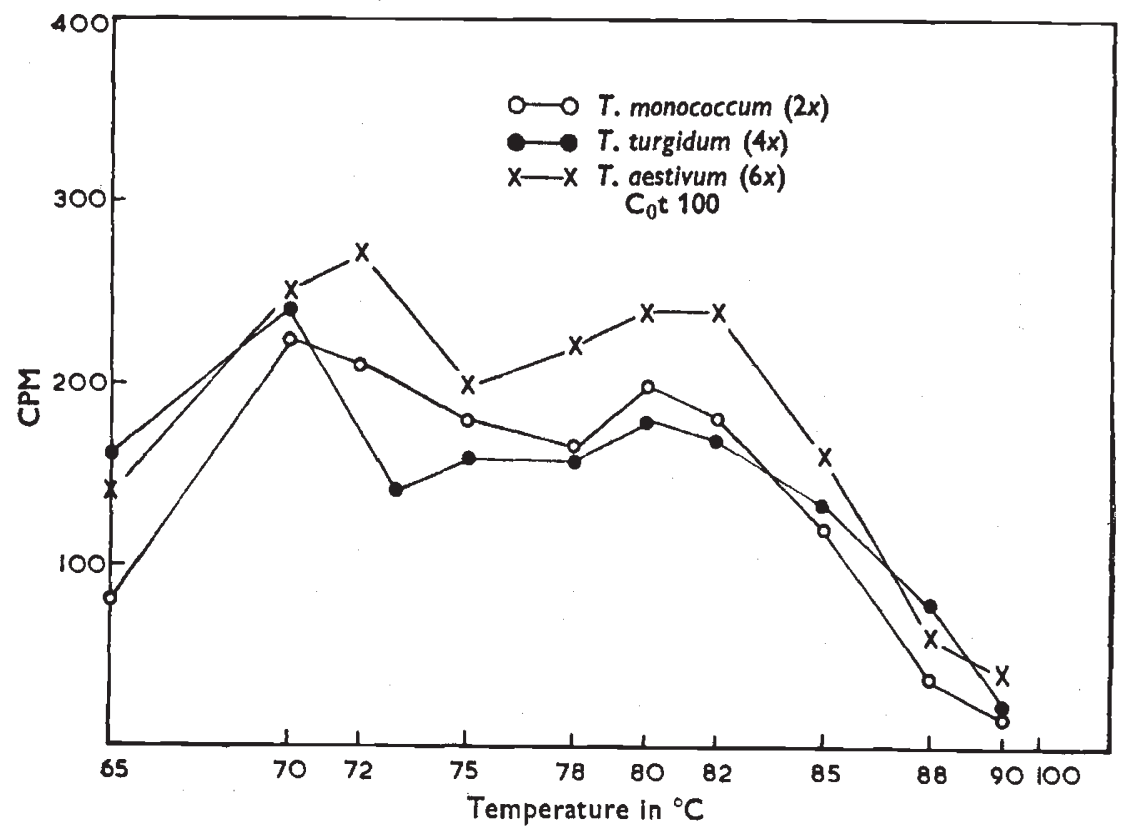

Fra. 2.-Elution profile of repeated DNA from HA column. Sheared ' (c.p.m. 14,040), and ${ }^{8} \mathrm{H}$-labelled turgidum (c.p.m. 3460) and aestivum (c.p.m. 11,660) DNAs were used to separate repeated DNA at $C_{0} t 100(100 \mu \mathrm{g} . / \mathrm{ml}$. DNA was used) by HA fractionation. Percentage reassociation recorded at this $C_{0} t$ was 69,81 and 82 respectively for monococcum, turgidum and aestivum. Isolated repeated DNA from monococcum (c.p.m. 1590), turgidum (c.p.m. 1610) and aestivum (c.p.m. 1992) was used for HA thermal chromatography (temperature range $65^{\circ}-100^{\circ} \mathrm{C}$ ) as described in Materials and methods. Recovery of repeated DNA from the column ranged from 92 to 97 per cent.

basis of the reassociation rate curve (fig. 1), are given respectively in figs. 2 and 3. It is evident from fig. 2 that the reassociated DNA bound to the HA elutes over wide range of temperature $\left(65^{\circ}-90^{\circ} \mathrm{C}\right)$. The elution pattern shows two peaks at $70^{\circ}$ and $80^{\circ} \mathrm{C}$ for $2 x$ and $4 x$ and at $72^{\circ}$ and $82^{\circ} \mathrm{C}$

81/2-R 
for $6 x$ wheat repeated DNAs. The elution pattern shows a melting profile of typically repeated DNA fractions. Melting of DNA at a particular temperature depends upon base composition and the extent of base of matching. Therefore, the broad curve indicates involvement of several families of repeated sequences with varying base pair matching.

Reassociated non-repeated DNA of $2 x, 4 x$ and $6 x$ wheat eluted mainly between $80^{\circ}$ and $90^{\circ} \mathrm{C}$. with the peak at $87^{\circ} \mathrm{C}$. (fig. 3). The $4 x$ wheat non-repeated DNA shows a slightly broader melting region. $T m$ for

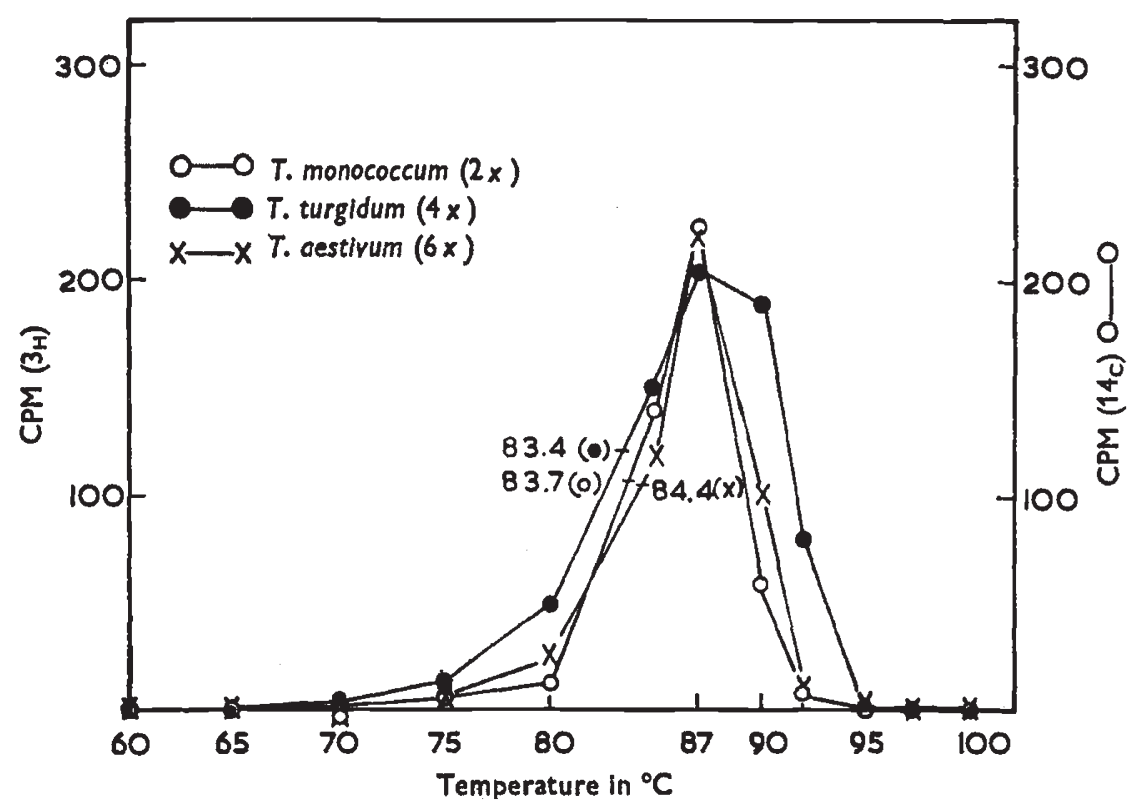

Fic. 3.-Elution profile of non-repeated DNA from HA column. Non-repeated DNA was prepared as described in Materials and methods. Each of the ${ }^{14} \mathrm{C}$-labelled non-repeated monococcum (c.p.m. 7020), ${ }^{3} \mathrm{H}$-labelled turgidum (c.p.m. 6820) and aestivum (c.p.m. 5830) DNA was mixed with respective homologous un-labelled non-repeated DNA in $1 \mathrm{ml}$. of $0.36 \mathrm{M} \mathrm{PB}$ at a final concentration of $3 \mu \mathrm{g}$. $/ \mathrm{ml}$. and dissociated at $100^{\circ}$ and reassociated at $60^{\circ} \mathrm{C}$ at $C_{0} t 14,100$. An aliquot of $0.1 \mathrm{ml}$. was diluted to $0.3 \mathrm{ml}$. with water and was used for HA thermal chromatography (temperature range $60^{\circ}-100^{\circ} \mathrm{C}$ ).

$2 x, 4 x$ and $6 x$ wheat non-repeated DNAs were $83.7,83.4$ and 84.4 respectively under these experimental conditions. These values were slightly lower than the melting temperature for native DNAs. This indicates high precision in base pair matching of the duplexes formed.

The reassociation rate curves, and the thermal elution patterns of reassociated DNAs reveal that diploid and polyploid wheat DNAs can be broadly separated as repeated and non-repeated fractions at around $C_{0} t 100$ under the experimental conditions used. The relative percentage of the repeated DNA at this $C_{0} t$ increases with ploidy as mentioned earlier. This is to be expected in polyploids originating from hybridisation of diploid species having a common ancestor. Working with the $2 c$ nuclei of diploids and polyploids among the cultivated and related species of wheat, Rees and Walters (1965) observed that, " the tetraploid and hexaploid DNA values are approximately twice and three times larger, respectively, than those of 
the diploids ", and they concluded that, "there is no evidence, either for an appreciable diminution, or for an increase of DNA per chromosome associated with the polyploidy". However, it is evident from the reassociation curve, that the $C_{0} t$ required for 50 per cent. reassociation $\left(C_{0} t \frac{1}{2}\right)$ of the slow fraction in $2 x$ wheat is less than that required for $4 x$ and $6 x$ wheat. As the $C_{0} t \frac{1}{2}$ is directly proportional to the amount of non-repeated DNA (Laird, 1971), an increase in $C_{0} t \frac{1}{2}$ implies a larger genome size (amount of non-repeated DNA). This increase in the amount of non-repeated DNA in the polyploid species probably indicates that the repeated sequences might have undergone considerable divergence during the course of evolution, and thus increasing the net amount of non-repeated sequences, though the total DNA content remains unchanged.

\section{(iii) Heterologous reassociation of repeated $D \mathcal{N} A$}

Homologous and heterologous reassociation of DNAs from different species is given in table 2. Concentration of DNA and time of incubation

TABLE 2

Reassociation of repeated DNA

\begin{tabular}{llcc} 
Source of & \multicolumn{1}{c}{$\begin{array}{c}\text { Source of } \\
\text { labelled DNA }\end{array}$} & $\begin{array}{c}\text { Percentage labelled } \\
\text { DNA reassociated } \\
\text { with unlabelled }\end{array}$ & $\begin{array}{c}\text { Percentage } \\
\text { relative } \\
\text { homology }\end{array}$ \\
T. monococcum (AA) & T. monococcum (AA) & $76 \cdot 6$ & 100 \\
T. monococcum (AA) & T. turgidum (AABB) & $56 \cdot 3$ & 61 \\
T. monococcum (AA) & T. aestivum (AABBD) & $38 \cdot 3$ & 50 \\
Ae. speltoides (BB) & Ae. speltoides (BB) & $75 \cdot 3$ & 100 \\
Ae. speltoides (BB) & T. turgidum (AABB) & $39 \cdot 6$ & 52 \\
Ae. speltoides (BB) & T. aestivum (AABBD) & $21 \cdot 8$ & 28 \\
Secale cereale (RR) & Secale cereale (RR) & $73 \cdot 1$ & 100 \\
Secale cereale (RR) & T. aestivum (AABBDD) & $43 \cdot 9$ & 59 \\
T. turgidum (AABB) & T. turgidum (AABB) & $77 \cdot 1$ & 100 \\
T. turgidum (AABB) & T. aestivum (AABBDD) & $48 \cdot 0$ & 62 \\
T. aestivum (AABBDD) & T. aestivum (AABBDD) & $77 \cdot 4$ & \\
T. aestivosecale & T. aestivosecale (AABBDDRR) & $75 \cdot 7$ & 100 \\
T. aestivosecale & T. aestivum (AABBDD) & $60 \cdot 9$ & 80
\end{tabular}

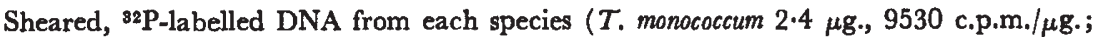

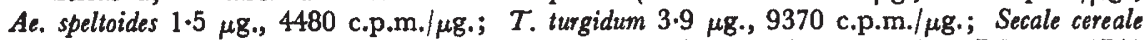

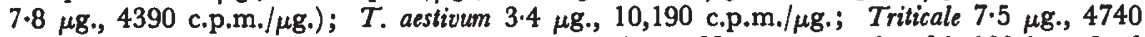
c.p.m./ $\mu$ g.) was mixed with the indicated unlabelled DNA in the ratio of $1: 100$ in a final volume of $1 \mathrm{ml}$. of $0.12 \mathrm{M} \mathrm{PB}$, dissociated at $100^{\circ} \mathrm{C}$ for 5 minutes and incubated at $60^{\circ} \mathrm{C}$ for different periods to achieve $C_{0} t 110$ for each interaction. Unreacted dissociated DNA was washed off the $\mathrm{HA}$ column at $60^{\circ} \mathrm{C}$. with $0.12 \mathrm{M} \mathrm{PB}$, reassociated DNA was eluted with $0.5 \mathrm{M} \mathrm{PB}$ at $98^{\circ} \mathrm{C}$. Self or heterologous reassociation of input labelled DNA when incubated with calf thymus DNA at the same $C_{0} t$ was in the range of 7-10 per cent. Reassociation values given in table are corrected for self reassociation.

used in these experiments resulted in $C_{0} t$ of 110 which permits reassociation, predominantly, of repeated DNA. Homologous reassociation varied from 73 to 77 per cent. Respective values for homologous reassociation have been 
considered as 100 in calculating percentage relative reassociation. Three diploid species considered, i.e. T. monococcum, Ae. speltoides and Secale cereale, showed respectively, 50, 28 and 59 per cent relative reassociation with $6 x$ wheat DNA. Similarly, T. monococcum and Ae. speltoides showed, respectively, 61 and 52 per cent relative reassociation with $4 x$ wheat DNA. Bendich and McCarthy (1970b) reported 84,83 and 80 per cent. relative reassociation of monococcum DNA with $6 x, 4 x$ wheat and $A e$. squarrosa DNA respectively when incubated at $C_{0} t$ of 12,000 . At this high $C_{0} t$ both repeated and nonrepeated DNA fractions got reassociated. Filter bound rye DNA showed

TABle 3

Reassociation of non-repeated DNA

\begin{tabular}{|c|c|c|c|}
\hline $\begin{array}{c}\text { Source of } \\
\text { labelled DNA }\end{array}$ & $\begin{array}{c}\text { Source of } \\
\text { unlabelled DNA }\end{array}$ & $\begin{array}{c}\text { Percentage labelled } \\
\text { DNA reassociated } \\
\text { with unlabelled } \\
\text { DNA }\end{array}$ & $\begin{array}{l}\text { Percentage } \\
\text { relative } \\
\text { re- } \\
\text { association }\end{array}$ \\
\hline $\begin{array}{l}\text { T. monococcum (AA) } \\
T . \text { monococcum (AA) } \\
T . \text { monococcum (AA) }\end{array}$ & $\begin{array}{l}T . \text { monococcum (AA) } \\
T . \text { turgidum (AABB) } \\
T . \text { aestivum (AABBDD) }\end{array}$ & $\begin{array}{l}94 \cdot 7 \\
91 \cdot 2 \\
90 \cdot 0\end{array}$ & $\begin{array}{r}100 \\
96 \\
95\end{array}$ \\
\hline T. aestivum (AABBDD) & $\begin{array}{l}T . \text { aestivum (AABBDD) } \\
T . \text { turgidum (AABB) } \\
\mathcal{T} \text {. monococcum (AA) }\end{array}$ & $\begin{array}{l}93 \cdot 8 \\
89 \cdot 5 \\
90 \cdot 5\end{array}$ & $\begin{array}{r}100 \\
95 \\
96\end{array}$ \\
\hline
\end{tabular}

Sheared, ${ }^{14} \mathrm{C}-$ labelled DNA of monococcum (325 $\mu \mathrm{g} ., 503$ c.p.m. $/ \mu \mathrm{g}$. in $3.25 \mathrm{ml}$. of $0.12 \mathrm{M}$ PB) and ${ }^{8} \mathrm{H}$-labelled aestivum DNA (425 $\mu \mathrm{g}$., c.p.m. $309 / \mu \mathrm{g}$. in $4.25 \mathrm{ml}$. $0.12 \mathrm{M} \mathrm{PB}$ ) were dissociated separately at $100^{\circ} \mathrm{C}$ and incubated for 100 hours at $60^{\circ} \mathrm{C}\left(C_{0} t=100\right)$. DNA which did not reassociate on incubation at $C_{0} t 100$, was separated by HA chromatography and was considered as non-repeated. Similarly, unlabelled DNA of monococcum, turgidum and aestioum was isolated after incubation at $C_{0} t 100.15 \mu \mathrm{g}$. (c.p.m. 2250) of labelled monococcum non-repeated DNA was mixed $1.5 \mathrm{mg}$. unlabelled non-repeated DNAs of monococcum, turgidum, or aestivum separately at a final volume of $1 \mathrm{ml}$. in $0.12 \mathrm{M} \mathrm{PB}$, dissociated and incubated at $60^{\circ} \mathrm{C}$ for 168 hours to achieve $C_{0} t 2486$. Similarly, aestivum non-repeated, labelled DNA (15 $\mu \mathrm{g}$., c.p.m. 1950) was mixed with unlabelled DNA of aestivum, turgidum and monococcum $(1.2 \mathrm{mg}$. each) at a final volume of $1 \mathrm{ml} .0 .36 \mathrm{M} \mathrm{PB}$, dissociated and incubated at $60^{\circ} \mathrm{C}$ for 220 hours to achieve $C_{0} t$ equivalent of 11,477 (relative to $0.12 \mathrm{M} \mathrm{PB}$ ). Self reassociation of labelled input DNA was 5.0 and 6.1 per cent respectively for monococcum and aestivum. Reassocia tion values given in the table have been corrected for self reassociation.

100 per cent relative binding to $6 x$ wheat DNA (Bendich and McCarthy, $1970 a$ ). In reciprocal experiments when $6 x$ wheat DNA was filter bound, relative reassociation was 60 per cent. Earlier, Bolton et al. (1965) had reported 75 per cent. relative reassociation between wheat, and rye DNA bound to agar. As described earlier, the DNA-DNA hybridisation method using filter or agar and short incubation time involves, predominantly, the reassociation of repeated DNA fractions.

These results indicate that the repeated DNA of diploid species have diverged from each other, yet they have to be a considerable degree repeated sequences in common. Our data, as well as those of Bendich and McCarthy $(1970 a)$, show greater percentage relative reassociation between $6 \times$ wheat and rye than between $6 x$ wheat and $2 x$ wheat. This seems difficult to accept, but it might be true! Sears (1968) has pointed out that genetically, rye chromosomes are " almost as closely related to their wheat homoelogues as the latter are to each other". Rye chromosomes do not generally pair with wheat chromosomes even in the absence of the 5B effect. Pairing 
behaviour of chromosomes can be altered by chromosomal inversions and translocations. It is also established that pairing of homoelogous as well as homologous chromosomes is controlled by specific genes (Feldman, 1968; Riley, 1968) and hence, the pairing behaviour of chromosomes may not truly represent homologies at the DNA level.

\section{(iv) Heterologous reassociation of non-repeated $D \mathcal{N} A$}

Because of the non-availability of seeds in large quantities from other diploid species, DNA reassociation studies with the non-repeated fraction were limited only to Triticum species. Results are given in table 3. At $C_{0} t$ of 2486 homologous reassociation of monococcum DNA was 94 per cent. Heterologous reassociation with $4 x$ and $6 x$ wheat DNAs was 91 and 90 per cent, respectively. Similarly, homologous reassociation of $6 x$ wheat DNA at $C_{0} t$ equivalent of 11,477 was 94 per cent, and heterologous reassociation with $2 x$ and $4 x$ wheat was 90.5 and 89.5 per cent, respectively. The results show that the non-repeated fractions have greater homologies. In other words they have not diverged to the same extent as the repeated DNA and appear to be more conservative in composition. More precise estimates of the divergence of non-repeated DNAs can be obtained by measuring the $T m$ of heteroduplexes. This work will be reported later. If it is true that the non-repeated DNA codes for proteins and enzymes while the repeated sequences are involved with gene regulation (Britten and Davidson, 1969), the present results in Triticinae would support the hypothesis that differences between species are largely due to differences in gene regulation.

Acknowledgment.-We are grateful to Dr R. Riley, F.R.S. (Cambridge) for providing some of the foundation seeds.

\section{REFERENCES}

BENDICH, A. J., AND Bolton, E. T. 1967. Relatedness among plants as measured by the DNA-agar technique, Plant. Physiol., 42, 959-967.

BENDICH, A. J., AND MCCARTHY, B. J. 1970a. DNA comparisons among barley, oats, rye and wheat. Genetics, 65, 545-565.

BENDICH, A. J., AND MCCARTHY, B. J. 1970b. DNA comparisons among some biotypes of wheat. Genetics, 65, 567-573.

BOLTON, E. T., BRITTEN, R. J., COWIE, D. B., ROBERTs, R. B., SZAFRANSKI, P., AND WARING, M. J. 1965. Carnegie Inst. Washington Year Book' '64, 313. 1965.

BRTrTEN, R. J. 1969. Repeated DNA and transcription. In Problems in Biology: RNA in Development (ed. E. W. Hanly), pp. 187-216. Univ. of Utah Press, Salt Lake City, 1970.

BRITTEN, R. J., AND DAVIDSON, E. H. 1969. Gene regulation for higher cells: a theory. Science, 165, 349-358.

BRITTEN, R. J., AND DAVIDSON, E. H. 1971. Repetitive and non-repetitive DNA sequences and a speculation on the origins of evolutionary novelty. Quart. Rev. Biol., 46, 111-138. BRITTEN, R. J., AND KOHNE, D. E. 1968. Repeated sequences in DNA. Science, 161, 529-540. BRTTTEN, R. J., AND KOHNE, D. E. 1969. Repetition of nucleotide sequences in chromosomal DNA. In Handbook of Molecular Cytology (ed. A Lima-de-Faria), pp. 22-36. NorthHolland Publishing Company, Amsterdam, 1969.

Carnegie Institution Washington Year Book'64-'70. (Issued between 1965-1971.)

CRICK, F. 1971. General model for chromosomes of higher organisms. Nature, 234, 25-27. FELDMAN, M. 1968. Regulation of somatic association and meiotic pairing in common wheat. Proc. Third International Wheat Genetics Symposium, Canberra, 169-178.

jornson, B. L. 1972. Protein electrophoretic profiles and the origin of the B genome of wheat (Triticum/Aegilops/amphiploids). Proc. nat. Acad. Sci., U.S., 69, 1398-1402.

krhara, H. 1944. Die Entdeckung der DD-Analysatoren beim Weizen. Nogyo Oyobi Engei, $19,889-890$.

$31 / 2-\mathrm{R} 2$ 
KIMBER, G., AND ATHWAL, R. s. 1972. A reassessment of the course of evolution of wheat. Proc. nat. Acad. Sci., U.S., 69, 912-915.

KOHNE, D. E. 1970. Evolution of higher organism DNA. Quart. Rev. Biophys., 3, 327-375.

LAIRD, C. D. 1971. Chromatid structure: relationship between DNA content and nucleotide sequence diversity. Chromosoma, 32, 378-406.

MARMUR, J. 1961. A procedure for the isolation of deoxyribonucleic acid from microorganisms. F. Mol. Biol., 3, 208.

MCFADDEN, E. S., AND BEARs, E. R. 1944. The artificial synthesis of Triticum spelta. Rec. Genet. Soc. Amer., 13, 26-27.

MCCARTHY, B. J., AND FARQUHAR, M. N. 1972. The rate of change of DNA in evolution. In Evolution of Gentic Systems (ed. H. H. Smith), pp. 1-43. Brook haven Symposium in Biology Number 23, Gordon and Breach Science Publishers, New York, 1972.

MITRA, R., AND BHATIA, C. R. 1971. Isoenzymes and polyploidy. I. Qualitative and quantitative isoenzyme studies in the Triticinae. Genet. Res., Camb., 18, 57-69.

MIYAZAWA, Y., AND THOMAS, C. A. 1965. Nucleotide composition of short segments of DNA molecules. F. Mol. Biol., 11, 223-237.

REes, H., AND WALTERs, M. R. 1965. Nuclear DNA and the evolution of wheat. Heredity, $20,73-82$.

RILEY, R. 1968. The basic and applied genetics of chromosome pairing. Proc. Third International Wheat Genetics Sympositu, Canberra, 185-195.

RILEY, R., UNRAV, J., AND CHAPMAN, v. 1958. Evidence on the origin of the B genome of wheat. F. Heredity, 49, 91-98.

SARKAR, P., AND STEBBINS, G. L. 1956. Morphological evidence concerning the origin of the B genome in wheat. Amer. F. Bot., 43, 297-304.

SEARs, E. R. 1968. Relationships in Triticinae-Discussion. Proc. Third International Wheat Genetics Symposium, Canberra, p. 165.

strbiss, G. L. 1956. Cytogenetics and evolution of the grass family. Amer. F. Bot., 43, 890-905.

VAN DER SCHANs, G. P., ALLEN, J. B. T., AND BLOCX, J. 1969. Determination of molecular weight distributions of DNA by means of sedimentation in a sucrose gradient. Analytical Biochem., 32, 14-30. 